\title{
PROVISIONAL PROGRAMME ADVANCES IN COMPUTER CHESS 8
}

\author{
June 27-28, 1996
}

Maastricht, The Netherlands

\begin{abstract}
The eighth conference on Advances in Computer Chess will be held under auspices of the International Computer Chess Association (ICCA) and the Max Euwe Centre (Amsterdam, The Netherlands) in Maastricht, the Netherlands, at Castle Vaeshartelt, $5 \mathrm{~km}$ from Maastricht centre and withın the suburbs of that city
\end{abstract}

\section{(Invited) speakers}

The programme includes several prominent speakers in the computer-chess research field The invited speakers are Turing Award winner Ken Thompson (Bell Laboratories, New Jersey, USA) and IGM David Bronsteın (Minsk, Russia)

\section{Thursday June 27, 1996}

Conference Chair Professor T A Marsland

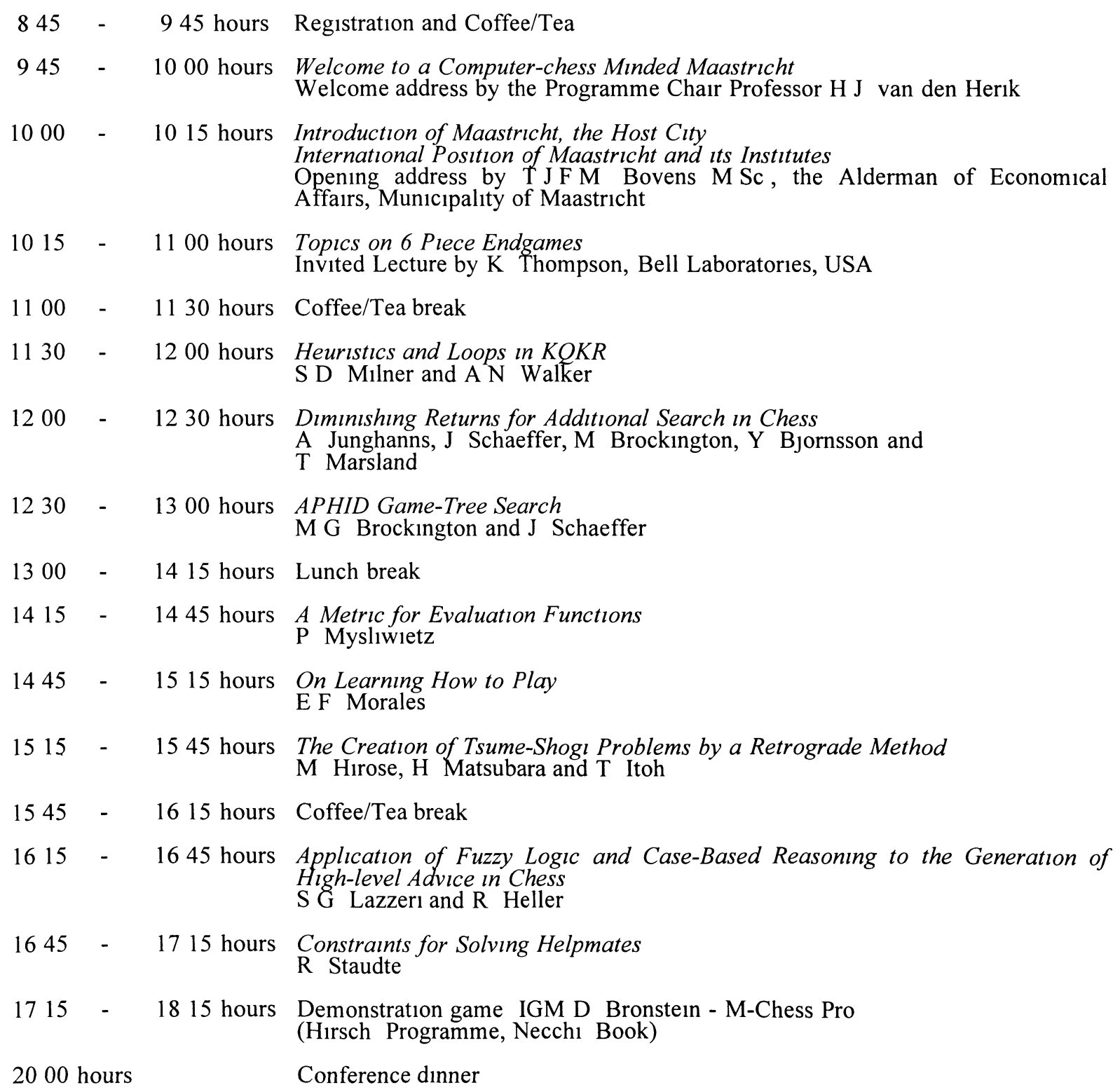


Friday June 28, 1996

Conference Chair: Professor H.J. van den Herik

\begin{tabular}{|c|c|c|c|}
\hline 9.00 & - & 9.30 hours & $\begin{array}{l}\text { New Advances in Adaptive Pattern-Orlented Chess } \\
\text { J. Allen, E. Hamilton and R. Levinson }\end{array}$ \\
\hline 9.30 & - & 10.00 hours & $\begin{array}{l}\text { SSSt } \\
\text { A. de Bruin and W. Pijls }\end{array}$ \\
\hline 10.00 & - & 10.30 hours & $\begin{array}{l}\text { Parallel Controlled Conspiracy-Number Search } \\
\text { U. Lorenz and V. Rottmann }\end{array}$ \\
\hline 10.30 & - & 11.00 hours & Coffee/Tea break \\
\hline 11.00 & - & 11.30 hours & $\begin{array}{l}\text { Fall-High Reductıons } \\
\text { R. Feldmann }\end{array}$ \\
\hline 11.30 & - & 12.15 hours & $\begin{array}{l}\text { My Experiences with Computers } \\
\text { Invited lecture by IGM D. Bronstein, Minsk, Russia }\end{array}$ \\
\hline 12.15 & - & 13.30 hours & Lunch break \\
\hline 13.30 & - & 14.00 hours & $\begin{array}{l}\text { Gains and Rusks of OM Search } \\
\text { H. Iida, I. Kotani, J.W.H.M. Uiterwijk and H.J. van den Herik }\end{array}$ \\
\hline 14.00 & - & 14.30 hours & $\begin{array}{l}\text { Searching with Uncertainty Cut-offs } \\
\text { Y Bjornsson, T. Marsland, J. Schaeffer and A. Junghanns }\end{array}$ \\
\hline 14.30 & - & 15.00 hours & Coffee/Tea break \\
\hline 15.00 & - & 15.30 hours & $\begin{array}{l}\text { Informatıon in Transposition Tables } \\
\text { D.M Breuker, J.W.H.M. Uiterwijk, and H.J. van den Herik }\end{array}$ \\
\hline 15.30 & - & 16.00 hours & $\begin{array}{l}\text { Decisıon Makıng under Uncertainty A Ratıonal Approach to Krıegspıel } \\
\text { P. Ciancarini, F. Dalla Libera, and F. Maran }\end{array}$ \\
\hline \multicolumn{3}{|c|}{16.00 hours } & $\begin{array}{l}\text { Lookıng Back and Ahead } \\
\text { Closing address by Professor Van den Herik }\end{array}$ \\
\hline
\end{tabular}

Sponsors

The conference is being sponsored by EuroChess Zentrale, Paardekooper \& Hoffmann, Max Euwe Centre, Municipality of Maastricht, Foundation Scientific Research Limburg (SWOL), SION, AEGON, Unıversity of Limburg, CSVN, PTT Telecom, SNS Bank, IBM Nederland N.V., and BSO Origin.

\section{Information}

For more information and a copy of the registration form please contact: Tons van den Bosch, University of Limburg, Department of Computer Science, P.O Box 616, 6200 MD Maastricht, The Netherlands, fax +31 43 3252392, e-mail: bosch@cs.rulimburg.nl.

\section{CALENDAR OF COMPUTER-GAMES EVENTS 1996}

June 27-28, 1996

The eighth conference of the Advances in Computer Chess, to be held in Maastricht, The Netherlands. For details see this issue pp. 141-142.

\section{August 23-30, 1996}

Uniform Platform Computer-Chess Tournament, to be held at the Queen Mary and Westfield College. Details from Don Beal, Queen Mary and Westfield College, Mile End Road London, E1 4NS, UK. Email: don@dcs.qmw.ac.uk.

\section{October 9-16, 1996}

The 1996 World Micro Computer Chess Championshıp to be held in Jakarta, Indonesia. For details see pp. 136-140 in this issue. 